\title{
Administration of PGF2 $\alpha$ and Antibiotic in Dairy Cows during Early Postpartum Period and Their Effect on Various Fertility Parameters
}

\author{
Akshay Sharma*, Madhumeet Singh, Amit Sharma and Pravesh Kumar
}

Department of Veterinary Gynecology and Obstetrics, College of Veterinary and Animal

Sciences, Himachal Pradesh Agricultural University, Palampur - 176062, India

*Corresponding author

\section{A B S T R A C T}

\begin{tabular}{|l|}
\hline Ke y w o r d s \\
$\begin{array}{l}\text { Dairy cows, PGF2 } \alpha, \\
\text { Antibiotic, Fertility } \\
\text { parameters }\end{array}$ \\
\hline Article Info \\
\hline $\begin{array}{l}\text { Accepted: } \\
\text { 30 July 2017 } \\
\text { Available Online: } \\
\text { 10 September } 2017\end{array}$ \\
\hline
\end{tabular}

\section{Introduction}

Reproductive performance in dairy cows is a key factor affecting profitability of the dairy industry (Galvao et al., 2013). Postpartum administration of $\mathrm{PGF}_{2} \alpha$ enhances the uterine contractility and lochial clearing from the uterus after calving (Nanda et al., 2003). Also, antibiotic administration helps in improving the uterine defense and consequently reducing persistent inflammation in the postpartum uterus (LeBlanc, 2008).

Therefore, the main objective of this study was to find the effectiveness of $\mathrm{PGF}_{2} \alpha$ and antibiotic administration during early postpartum period on fertility parameters in dairy cows.
The objective of this study was to investigate the effect of $\mathrm{PGF}_{2} \alpha$ and antibiotic treatment on fertility parameters in dairy cows. After parturition, 24 cows were assigned into four treatment groups which were $\mathrm{PGF}_{2} \alpha$ conception in all the groups. Dairy cows treated with $\mathrm{PGF}_{2} \alpha$ on day 8 after calving were having numerical difference but there was no statistical difference $(\mathrm{P}>0.05)$ in fertility parameters recorded.

\section{Materials and Methods}

The study was carried out on 24 postparturient dairy cows (Jersey and Jersey crossbred) of Livestock farm, CSKHPKV, Palampur. Dairy cows of first two treatment groups were administered with $500 \mu \mathrm{g} \mathrm{PGF}_{2} \alpha$ analogue (Cloprostenol; Zydus Animal Health Ltd.) intramuscularly either on day 8 (PG8) or 25 (PG25) postpartum. In third group, cows were administered with antibiotic Ciprofloxacin intramuscularly for first 5 days after calving (C-Flox Power; Intas Pharmaceuticals Ltd.). The fourth group served as untreated control $(n=6$ in each group). Postpartum reproductive performance was assessed by evaluation of days to first artificial insemination (AI), number of inseminations per conception and calving to 
conception interval (days open), which was followed by pregnancy diagnosis (60 days after successful AI) in different treatment and control groups. The data was statistically analyzed using one way ANOVA with SAS (Statistical Analysis Software), SAS® 9.2 TS Level version $2 \mathrm{M} 2$ for windows.

\section{Results and Discussion}

The present study revealed that the time required for mean time required for days to first A.I. was numerically shorter $(86.00 \pm 4.21$ days pp) in the PG8 group while in PG25, antibiotic and control group, it was $97.67 \pm 7.58,94.33 \pm 6.96$ and $97.00 \pm 8.99$ days, respectively. However, there was no significant difference $(\mathrm{P}>0.05)$ between different treatment and control groups. Sharawy et al., (2015) also reported a shorter interval from calving to first A.I. (i.e. $60.94 \pm$ 2.9 days pp) without significant effect of $\mathrm{PGF}_{2} \alpha$ administration during early postpartum period. During early postpartum period, exogenous $\mathrm{PGF}_{2} \alpha$ administration can increase the rate of uterine involution which results in evacuation of bacterial contamination from the uterus and subsequently improve conception rate (Nanda et al., 2003). Contrarily, administration of $\mathrm{PGF}_{2} \alpha$ during the early postpartum phase was associated with improvement in fertility (Pankowski et al., 1995; Melendez et al., 2004). However, the mean number of inseminations required for conception were less $(1.33 \pm 0.21)$ in antibiotic group while in PG8, PG25 and control group, these were $1.50 \pm 0.22$, $1.50 \pm 0.22$ and $1.66 \pm 0.21$, respectively.

Mean time required for calving to conception interval was comparatively shorter (96.50 \pm 6.42 days postpartum) in PG8 group while in PG25, antibiotic and control group, it was $106.50 \pm 10.85, \quad 101.33 \pm 9.46$ and $111.00 \pm 11.45$ days postpartum, respectively without any significant difference $(\mathrm{P}>0.05)$ between different treatment and control groups. Our observations support the findings of $\mathrm{PGF}_{2} \alpha$ in the early postpartum period (between 7 and 28 days) reduced the postpartum interval to conception (Sharawy et al., 2015; Sani et al., 2016) and had a positive effect on reproductive performance (Nakao et $a l .$, 1997). On the other hand, administration of $\mathrm{PGF}_{2} \alpha$ did not result in any beneficial effect in terms of days open (Sharawy et al., 2015).

The main objective of antibiotic administration was to eliminate the pathogens from the uterus, the induction of the uterine immune system, elimination of the adverse effects of inflammation products on fertility and improvement in future reproductive performance (LeBlanc, 2008). However, antibiotic administration produced no significant difference $(\mathrm{P}>0.05)$ from other treatment and control groups in this study.

In conclusion, the administration of $\mathrm{PGF}_{2} \alpha$ and antibiotic in the immediate postpartum period does not improve the reproductive performance significantly, in dairy cows. So, given treatment is not effective after parturition, in order to improve the subsequent reproductive performance.

\section{Acknowledgement}

I would like to thank Dr. Madhumeet Singh for the precious and timely guidance which helped me in the completing my research work. Also, Dr. Amit Sharma and Dr. Pravesh Kumar helped me during my research and I would like to appreciate their efforts. This research did not receive any specific grant from funding agencies in the public, commercial or not-for-profit sectors.

\section{References}

Galvao, K.N., Federico P, De Vries A, Schuenemann GM, 2013. Economic comparison of reproductive programs 
for dairy herds using estrus detection, timed artificial insemination, or a combination. J Dairy Sci 96: 26812693.

LeBlanc, S., 2008. Postpartum uterine disease and dairy herd reproductive performance- A review. The Vet J 176: $102-114$.

Melendez, P., McHale J, Bartolome J, Archbald LF, Donovan GA, 2004. Uterine involution and fertility of Holstein cows subsequent to early postpartum PGF2 $\alpha$ treatment for acute puerperal metritis. J Dairy Sci 87(10): 3238-3246.

Nakao, T., Gamal A, Osawa T, Nakada K, Moriyoshi M, Kawata K, 1997. Postpartum plasma PGF metabolite profile in cows with dystocia and/or retained placenta, and effect of fenprostalene on uterine involution and reproductive performance. J Vet Med Sci 59(9): 791-794.
Nanda, A.S., Brar PS, Prabhakar S, 2003. Enhancing the reproductive performance in dairy buffaloes: major constrains and achievement. Reprod Suppl 61: 27-36.

Pankowski, J.W., Galton DM, Erb HN, Guard CL, Grohn YT, 1995. Use of $\mathrm{PGF}_{2} \alpha$ as a postpartum reproductive management tool for lactating dairy cows. J Dairy Sci 78(7): 1477-1488.

Sani, R.N., Mohammadi HR, Mahdavi A, Dadashpour H, 2016. Effects of different regimens of $\mathrm{PGF}_{2} \alpha$ treatment during postpartum on reproductive performance in dairy cows. Braz $\mathrm{J}$ Vet Res a Sci 53(4): 1-9.

Sharawy, S., Saleh N, Ghanem M, and Hassan S, 2015. Effect of different treatments at early postpartum period on uterine involution and subsequent reproductive performance in dairy cows. Glob Anim Sci J 3: 155-161.

\section{How to cite this article:}

Akshay Sharma, Madhumeet Singh, Amit Sharma and Pravesh Kumar. 2017. Administration of PGF2 $\alpha$ and Antibiotic in Dairy Cows during Early Postpartum Period and Their Effect on Various Fertility Parameters. Int.J.Curr.Microbiol.App.Sci. 6(9): 3738-3740. doi: https://doi.org/10.20546/ijcmas.2017.609.461 